\title{
PENGUKURAN KINERJA PERUSAHAAN DAN SISTEM MANAJEMEN STRATEGIS
}

\author{
Yoyon Safrianto \\ Universitas Teuku Umar/Fakultas Ekonomi, Meulaboh \\ Email: yoyonsafrianto@gmail.com
}

\begin{abstract}
Nowadays, the companies are in the middle of the information competition century. To achieve competitive success, the century information environment requires the new ability of the companies must be owned by the manufacturing and services. A company's ability to process information from a variety of instruments is absolutely need, steer the company to across the complex competitive environment. Company requires instrument which capable of explaining various aspects of the environment and performance in monitoring of travel towards a promising future. Balanced Scorecard provides an instrument that is required to steer the company toward the future success of the competition. An accurate understanding about the goals and methods for achieving it is very vital. Balanced Scorecard translates mission and strategy of the company in to a comprehensive measure that provides a framework for measurement and strategic management system. Scorecard measures the performance of companies on the four perspectives of balanced: financial, customer. internal business processes, and learning growth. Balanced Scorecard enables companies to record financial performance results as well as monitor progress in building the company's ability and to obtain intangible assets that required for future growth.
\end{abstract}

Keywords: balanced scorecard, performance, and trategic management system

\section{PENDAHULUAN}

Lingkungan operasi baru (New OperatingEnvironment) perusahaan abad informasi dibangundengan seperangkat asumsi operasi yang baru (Kaplan \& Norton, 2000:3)

a. Lintas Fungsi (Cross Function), para manajer tidak semata-mata memperhatikan fungsinya, tetapi menerapkan integrasi fungsi yang bertujuan untuk mengurangi friksi dan konflik, mempercepat proses produksi, cepat menanggapi dan mengatasi keluhan pelanggan. 
b. Hubungan Pelanggan dan Pemasok (Links toCustomer and Suplier), perusahaan berhubungandengan pelanggan dan pemasok melalui transaksi bisnis yang wajar (arm's-length transactions). Perusahaan menciptakan kegiatan terpadu, dengan tujuan, menciptakan efisiensi, meningkatkan kualitas, antisipasi waktu sepanjang rantai nilai (value chain), teknologi informasi dapat mendukungnya.

c. Segmentasi Pelanggan (Customer Segmentation), perusahaan harus belajar menyediakan produk dan jasa yang sesuai dengan pesanan segmen pelanggan yang berbeda, tanpa harus dibebani pengeluaran biaya operasi perusahaan yang tinggi, karena produksi yang sangat bervariasi dan bervolume rendah.

d. Skala Global (Global Scale), dalam masyarakat global pembatasan negara tidak mempengaruhi persaingan. Persaingan pokok antara perusahaan domestik dengan perusahaan internasional adalah pada sistem informasi.

e. Inovasi (Innovation), penemuan baru (invention) dan pembaharuan (innovation) merupakan faktor yang sangat penting bagi perusahaan. Penelitian dan pengembangan menjadi sangat penting untuk mewujudkan keunggulan kompetitif (competitiveadvantage).

f. Pekerja Keras yang berpengetahuan (KnowledgeWorker), semua pekerja harus memberikankontribusi nilai sesuai dengan apa yang mereka ketahui dan dengan informasi yang dapat mereka berikan. Melakukan investasi, mengelola dan mengembangkan pengetahuan setiap pekerja menjadi amat penting bagi keberhasilan perusahaan.

Dalam upaya mengubah diri agar berhasil dalam persaingan di masa depan, banyak perusahaan berpaling kepada sejumlah inisiatif perbaikan antara lain:

- Manajemen mutu terpadu (TQM)

- Sistem produksi dan distribusi Just In Time

- Persaingan berdasarkan waktu

- Produksi yang ramping

- Membangun perusahaan yang berpusatkan pelanggan (customer-focused)

- Manajemen biaya berdasarkan aktivitas

- Pemberdayaan pekerja

- Rekayasa ulang

Setiap program perbaikan ini terbukti telah mampu menghasilkan kesuksesan.Masing- masing program bersaing untuk mendapatkan waktu, energi dan sumber daya para eksekutif.Dan setiap program menawarkan terobosan kinerja dan penciptaan nilai yang meningkat atas unsur perusahaan.Tujuan program-program ini bukanlah kepada perbaikan kinerja incremental atau untuk sekedar bertahan hidup; tujuannya adalah kinerja yang diskontinyu, yang memungkinkan perusahan berhasil dalam persaingan di abad informasi ini.

Namun banyak dari program perbaikan ini memberikan hasil yang mengecewakan.Program-program tersebut seringkali terfragmentasi.Tidak terkait dengan strategi perusahaan, atau memberikan hasil yang berarti secara finansial dan ekonomis.Terobosan kinerja memerlukan manajemen yang digunakan oleh sebuah perusahaan. Perjalanan menuju masa depan yang lebih kompetitif, padat teknologi 
dan ditentukan oleh kapabilitas tidak dapat dicapai semata-mata melalui pemantauan dan pengendalian berbagai ukuran kinerja finansial masa lalu.

Saat ini, ada tiga model sistem pengukuran kinerja terintegrasi yang sangat populer dan digunakan secara luas di dunia industri atau perusahaan yaitu: Balanced Scorecard dari HarvardBusiness School, Integrated Performance Measurement System (IPMS) dari Centre for Strategic Manufacturing University of Strathclyde, dan Performance Prism dari kolaborasi antara Accenure dengan Cranfield School of Management (CambridgeUniversity) (Neely \& Adams, 2000).

Balanced scorecard dikembangkan padatahun 1993 oleh Prof. Robert Kaplan dan David Norton, dari Harvard Businesss School dan hingga kini masih terus diperbaiki (David, 2006 : 226). Kaplan \& Norton (2000 : 17) mengemukakan, Balanced scorecard adalah suatu kerangka kerjauntuk mengintegrasikan berbagai ukuran yang diturunkan dari strategi perusahaan, yaitu ukuran kinerja finansial masa lalu dan memperkenalkan pendorong kinerja finansial masa depan, yang meliputi perspektif pelanggan, proses bisnis internal, dan pembelajaran serta pertumbuhan, diturunkan dari proses penerjemahan strategi perusahaan yang dilaksanakan secara eksplisit dan ketat ke dalam berbagai tujuan dan ukuran yang nyata. Walaupun demikian, Balanced Scorecard bukan merupakan sistem pengukuran semata. Berbagai perusahaan yang inovatif menggunakan scorecard sebagai kerangka kerja proses manajemen perusahaan. Pearson and Robinson (2007 : 254) mendefinisikan balancedscorecard sebagai satu kumpulan dari empat ukuranyang berkaitan langsung dengan strategi suatu perusahaan: kinerja keuangan, pengetahuan mengenai pelanggan, proses bisnis internal, serta pembelajaran dan pertumbuhan.

Balanced Scorecard (kartu stok berimbang)merupakan sekelompok ukuran yang berkaitan langsung dengan strategi suatu perusahaan.BalanceScorecard mengarahkan suatu perusahaan untukmengaitkan strategi jangka panjangnya dengan sasaran dan tindakan yang nyata.Balanced Scorecard, seperti yang disajikan pada gambar 1, mengandung definisi yang tepat mengenai visi dan strategi perusahaan. Visi dan strategi tersebut dikelilingi oleh empat kotak tambahan. Setiap kotak mencerminkan perspektif yang memiliki tujuan, ukuran, target, dan inisiatif (Pearson and Robinson, 2007 : 255).
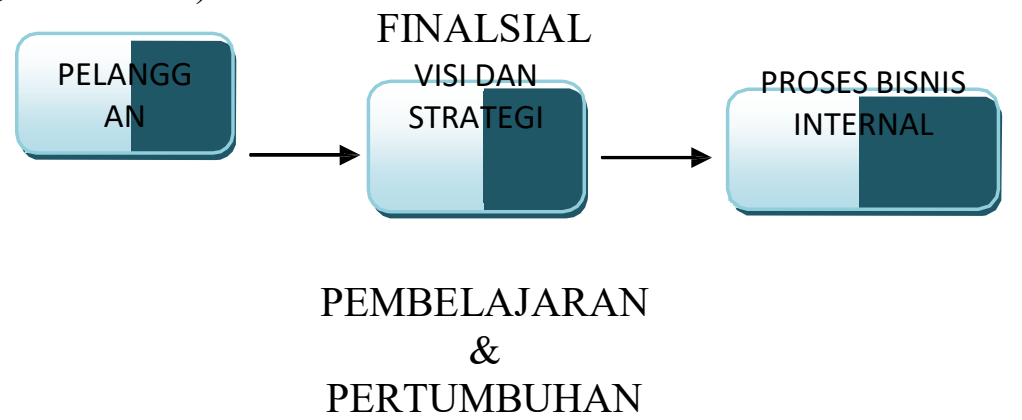

Gambar 1. Balanced Scorecard, Memberi Kerangka Kerja untuk Penerjemahan Visi dan Strategi ke dalam Empat Perspektif 
Sumber: Kuncoro, $2005: 297$

\section{Mengapa Balanced Scorecard dibutuhkan?}

Ada prinsip yang menyatakan: "If you can't measure it, you can't manage it." Sistem pengukuran yang diterapkan perusahaan mempunyai pengaruh yang sangat besar terhadap perilaku manusia di dalam maupun di luar organisasi.Untuk berhasil dan tuimbuh dalam persaingan abad informasi, perusahaan harus menggunakan sistem pengukuran dan manajemen yang diturunkan dari strategi dan kapabilitas yang dimiliki perusahaan. Sayangnya, banyak perusahaan yang mencanangkan strategi tentang hubungan dengan pelanggan, kompetensi utama, dan kapabilitas perusahaan ketika proses memotivasi dan mengukur kinerja masih dilaksanakan dengan menggunakan berbagai ukuran finansial. Tekanan pengukuran kinerja pada ukuran finansial, yang merupakan "language of business" ternyata tidak cukup. (Kaplan \& Norton, 2000 : 19)

Oleh karena itu diperlukan pengukuran kinerja terpadu, yaitu ukuran keuangan dan non keuangan.Pengukuran kinerja terpadu adalah pengukuran keuangan yang dipadukan dengan pelanggan (customer), proses internal, para pekerja dan sebagainya.Salah satu bentuk pengukuran kinerja terpadu adalah Balanced Scorecard. BalancedScorecard tetap mempertahankan ukuran finansialsebagai suatu ringkasan penting kinerja material dan bisnis, hanya ditambah dengan seperangkat ukuran yang lebih luas dan terpadu, yang mengaitkan pelanggan perusahaan saat ini, proses internal, kinerja pekerja dan sistem dengan keberhasilan finansial jangka panjang.

Balanced Scorecard melengkapi seperangkatukuran finansial kinerja masa lalu dengan ukuran pendorong (drivers) kinerja masa depan. Tujuan dan ukuran scorecard diturunkan dari visi dan strategi. Tujuan dan ukuran memandang kinerja perusahaan dari empat perspektif: finansial, pelanggan, proses bisnis internal, serta pembelajaran dan pertumbuhan. Empat perspektif ini memberi kerangka kerja bagiBalanced Scorecard (David, $2006: 450$ )

\section{BALANCED SCORECARDSEBAGAI SISTEM MANAJEMEN}

Balanced Scorecard menekankan ukurankinerja terpadu dan merupakan bahagian sistem informasi kepada karyawan (information system foremployee) pada setiap jenjang organisasi. "Karyawangaris depan (front line employee) harus mengerti konsekwensi keuangan dari keputusan dan tindakan mereka; para eksekutif senior harus memahami berbagai faktor yang mendorong keberhasilan finansial jangka panjang. Tujuan dan ukuran dalam Balanced Scorecard lebih dari sekedar sekumpulanukuran kinerja finansial dan nonfinansial khusus; semua tujuan dan ukuran ini diturunkan dari suatu proses atas ke bawah (top-down) yang digerakkan oleh misi dan strategi unit bisnis. 
Balanced Scorecard seharusnya menerjemahkanmisi dan strategi unit bisnis ke dalam berbagai tujuan dan ukuran.Balanced Scorecard menyatakan adanya keseimbangan antara berbagai ukuran eksternal para pemegang saham dan pelanggan, dengan berbagai ukuran internal proses bisnis penting, inovasi, serta pembelajaran dan pertumbuhan. Keseimbangan juga dinyatakan antara semua ukuran hasil - apa yang dicapai oleh perusahaan pada waktu yang lalu - dengan semua ukuran faktor pendorong kinerja masa depan perusahaan. Scorecard juga menyatakan keseimbangan antara semua ukuran hasil yang objektif dan mudah dikuantifikasi dengan faktor penggerak kinerja berbagai ukuran hasil yang subjektif dan agak berdasarkan pertimbangan sendiri.

Balanced Scorecard lebih dari sekedar sistempengukuran taktis atau operasional.Perusahaan yang inovatif menggunakan scorecard sebagai sebuah system manajemen strategis, untuk mengelola strategi jangka panjang. Perusahaan menggunakan fokus pengukuran scorecard untuk menghasilkan berbagai proses manajemen penting:

1. Memperjelas dan menerjemahkan visi dan strategi.

Proses scorecard dimulai dengan tim manajemen puncak yang bersama -sama bekerja menerjemahkan strategi unit bisnis ke dalam berbagai tujuan strategis yang spesifik. Untuk menetapkan berbagai tujuan finansial, tim ini harus mempertimbangkan apakah akan menitikberatkan kepada pertumbuhan pendapatan dan pasar, profitabilitas atau menghasilkan arus kas (cash flow). Khusus untuk perspektif pelanggan, tim manajemen harus menyatakan dengan jelas pelanggan dan segmen pasar yang diputuskan untuk dimasuki.

Setelah tujuan finansial dan pelanggan ditetapkan, perusahaan kemudian mengidentifikasi berbagai tujuan dan ukuran proses bisnis internal. Identifikasi semacam ini merupakan salah satu inovasi dan manfaat utama dari pendekatan scorecard.Keterkaitan yang terakhir, tujuan pembelajaran dan pertumbuhan, memberi alasan logis terhadap adanya kebutuhan investasi yang besar untuk melatih ulang para pekerja, dalam teknologi dan sistem informasi, serta dalam meningkatkan berbagai prosedur organisasional. Semua investasi dalam sumber daya manusia, sistem dan prosedur menghasilkan inovasi dan perbaikan yang nyata pada proses bisnis internal, untuk kepentingan pelanggan dan pada akhirnya, untuk kepentingan para pemegang saham.

2. Mengkomunikasikan dan mengaitkan berbagai tujuan dan ukuran strategis.

Tujuan dan ukuran strategis BalancedScorecard dikomunikasikan ke seluruh organisasimelalui surat edaran, papan bulletin, video dan bahkan secara elektronis melalui jaringan komputer. Komunikasi tersebut memberi informasi kepada semua pekerja mengenai berbagai tujuan penting yang harus di capai agar strategi organisasi berhasil.Beberapa perusahaan berusaha untuk menguraikan ukuran strategis tingkat 
tinggi scorecard unit bisnis ke dalam ukuran yang lebih spesifik pada tingkat operasional.

Scorecard juga memberi dasar untukmengkomunikasikan strategi unit bisnis untuk mendapatkan komitmen para eksekutif korporasi dan dewan direksi.Scorecard mendorong adanya dialog antara unit bisnis dengan eksekutif korporasi dan anggota dewan direksi. Dialog tersebut tidak hanya mengenai sasaran-sasaran finansial jangka pendek, tetapi juga mengenai perumusan dan pelaksanaan strategi yang menghasilkan terobosan kinerja masa depan. Di akhir proses pengkomunikasian dan pengaitan, setiap orang di dalam perusahaan seharusnya sudah memahami tujuan-tujuan jangka panjang unit bisnis dan juga strategi untuk mencapai tujuan-tujuan tersebut.

3. Merencanakan, menetapkan sasaran dan menyelaraskan berbagai inisiatif strategis

Balanced Scorecard akan memberi dampakterbesar ketika dimanfaatkan untuk mendorong terjadinya perubahan perusahaan. Untuk itu para eksekutif senior harus menentukan sasaran bagi berbagai ukuran scorecard untuk tiga atau lima tahunan, yang jika berhasil dicapai, akan mengubah perusahaan. Sasaran-sasaran tersebut harus mencerminkan adanya perubahan dalam kinerja unit bisnis.Jika unit bisnis tersebut adalah perusahaan publik, maka pencapaian sasaran harus menghasilkan harga saham yang meningkat dua kali lipat atau lebih. Sedang sasaran keuangan antara lain pelipatgandaan tingkat pengembalian investasi modal atau peningkatan penjualan sebesar $150 \%$ selama lima tahun berikutnya.

Untuk mencapai tujuan finansial yang ambisius seperti itu, para manajer harus mengidentifikasi rentang sasaran pelanggan, proses bisnis internal, tujuan pembelajaran dan pertumbuhan. Sasaran- sasaran ini dapat berasal dari berbagai sumber.Sasaran ukuran pelanggan seharusnya berasal dari upaya untuk memenuhi atau melampaui ekspektasi pelanggan.Benchmarking dapat dipakai agar praktek ternaik yang ada dapat disertakan untuk memeriksa apakah sasaran-sasaran yang diusulkan secara internal mampu membuat unit bisnis memenuhi berbagai ukuran strategi yang telah ditetapkan.

4. Meningkatkan umpan balik dan pembelajaran strategis.

Proses manajemen yang terakhir menyertakan Balanced Scorecard dalam suatu kerangkapembelajaran strategi. Proses ini adalah yang paling inovatif dan merupakan aspek yang paling penting dari seluruh proses manajemen scorecard. Proses ini memberikan kapabilitas bagi pembelajaran perusahaan pada tingkat eksekutif. BalancedScorecard memungkinkan manajer memantau danmenyesuaikan pelaksanaan strategi, dan, jika perlu membuat perubahan-perubahan mendasar terhadap strategi itu sendiri. Proses pembelajaran strategis mendorong timbulnya proses penetapan visi dan strategi baru di mana tujuan dalam berbagai perspektif di tinjau ulang, diperbaharui dan diganti agar sesuai dengan pandangan terkini mengenai 
hasil strategis dan pendorong kinerja yang dibutuhkan untuk periode mendatang. (Kaplan \& Norton, $2000: 13$ )

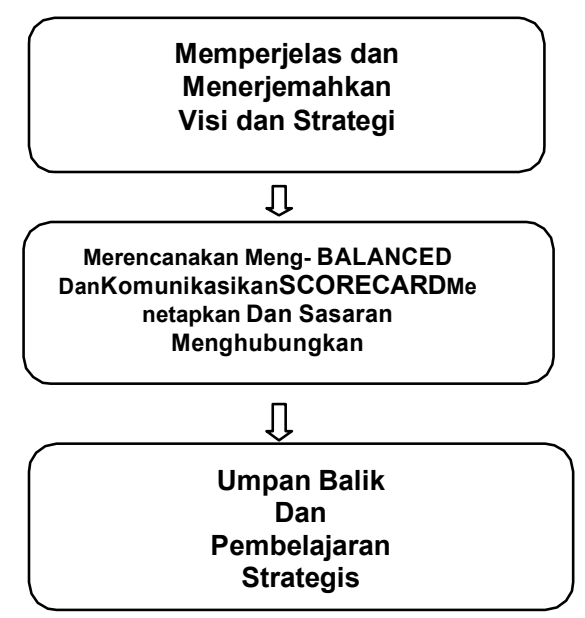

Gambar 2.Balanced Scorecard Sebagai Kerangka KerjaTindakan Strategis Sumber: Kaplan \& Norton (2000 : 11)

\section{EMPAT PERSPEKTIF BALANCE SCORECARD}

\section{Perspektif Finansial}

Balanced Scorecard tetap menggunakanperpektif finansial, karena ukuran finansial sangat penting dalam memberikan ringkasan konsekwensi tindakan ekonomis yang sudah diambil.Ukuran kinerja finansial memberikan petunjuk apakah strategi perusahaan, implementasi dan pelaksanaannya memberikan kontribusi atau tidak kepada peningkatan laba perusahaan. Tujan finansial biasanya berhubungan dengan profitabilitas, yang diukur misalnya oleh laba operasi, return on capitalemployed (ROCE), nilai tambah ekonomis (economic value added). Tujuan finansial lainnya, mungkinberupa pertumbuhan penjualan yang cepat atau terciptanya arus kas (Grant, $1997: 33$ ).

Tujuan finasial mungkin sangat berbeda untuk setiap tahap siklus hidup bisnis.Teori strategi bisnis menawarkan beberapa strategi yang berbeda yang dapat diikuti oleh unit bisnis, dari pertumbuhan pasar yang agresif sampai kepada konsolidasi bisnis, keluar dan likwidasi. Pada umumnya ada tiga tahap:

\section{a. Growth}

Perusahaan yang sedang bertumbuh berada pada awal siklus hidup perusahaan.Mereka menghasilkan produk dan jasa yang memiliki potensi pertumbuhan. Untuk memanfaatkan potensi ini, mereka harus melibatkan sumber daya yang cukup banyak untuk mengembangkan dan meningkatkan berbagai produk dan jasa baru; membangun dan memperluas fasilitas produksi; membangun kemampuan operasi, menanamkan investasi dalam sistem, infrastruktur dan jaringan 
distribusi yang akan mendukung terciptanya hubungan global; dan memelihara serta mengembangkan hubungan yang erat dengan para pelanggan. Perusahaan dalam tahap pertumbuhan mungkin beroperasi dengan arus kas yang negatif dan pengembalian modal investasi yang rendah.Tujuan finansial keseluruhan perusahaan dalam tahap pertumbuhan adalah persentase tingkat pertumbuhan pendapatan, dan tingkat pertumbuhan penjualan di berbagai pasar sasaran, kelompok pelanggan dan wilayah.

b. Sustain

Sebagian besar unit bisnis dalam sebuah perusahaan mungkin berada pada tahap bertahan, situasi dimana unit bisnis masih memiliki daya tarik bagi penanaman investasi dan investasi ulang, tetapi diharapkan mampu menghasilkan pengembalian modal yang cukup tinggi.Unit bisnis seperti ini diharapkan mampu mempertahankan pangsa pasar yang dimiliki dan secara bertahap tumbuh tahun demi tahun.Tujuan finansial di tahap bertahan biasanya terkait dengan profitabilitas, dinyatakan dengan memakai ukuran yang terkait dengan laba akuntansi seperti laba operasi dan marjin kotor.Ukuran ini menganggap investasi modal di dalam unit bisnis sudah tetap (given/exogenous) dan meminta para manajer untuk memaksimalkan pendapatan yang dihasilkan dari investasi modal.

\section{c. Harvest}

Sebagian unit bisnis akan mencapai tahap kedewasaan dalam siklus hidupnya, tahap dimana perusahaan ingin "menuai" investasi yang dibuat pada dua tahap sebelumnya. Bisnis tidak lagi membutuhkan investasi yang besar, cukup untuk pemeliharaan peralatan dan kapabilitas, bukan perluasan atau pembangunan berbagai kapabilitas baru.Setiap proyek investasi harus memiliki periode pengembalian investasi yang definitif dan singkat.Tujuan utamanya adalah memaksimalkan arus kas ke korporasi.Tujuan finansial keseluruhan untuk bisnis pada tahap menuai adalah arus kas operasi dan penghematan berbagai kebutuhan modal kerja.

Dengan demikian, jelas bahwa tujuan finansial di setiap tahap sangat berbeda. Tujuan finansial di tahap pertumbuhan akan menekankan pertumbuhan penjualan di pasar baru, kepada pelanggan baru dan dihasilkan dari produk dan jasa baru, mempertahankan tingkat pengeluaran yang memadai untuk pengembangan produk dan proses, sistem, kapabilitas pekerja, penetapan saluran pemasaran, penjualan dan distribusi baru. Tujuan finansial di tahap bertahan akan bertumpu pada ukuran finansial tradisional, seperti $R O C E$, laba operasi dan marjin kotor. Semua ukuran ini menyatakan tujuan finansial klasik, menghasilkan tingkat pengembalian modal investasi yang tinggi. Dan tujuan finansial perusahaan di tahap menuai akan menekankan pada arus kas. Setiap investasi harus memberikan pengembalian kas yang segera dan pasti.

Pengembangan sebuah Balanced Scorecard oleh karenanya harus dimulai dengan suatu dialog aktif antara $C E O$ unit bisnis dengan $C F O$ korporasi menyangkut berbagai kategori dan tujuan finansial spesifik unit bisnis.

2. Perspektif Pelanggan 
Dalam perspektif pelanggan BalancedScorecard, para manajer mengidentifikasi pelanggandan segmen pasar dimana unit bisnis tersebut akan bersaing dan berbagai ukuran kinerja unit bisnis di dalam segmen sasaran. Perspektif ini biasanya terdiri atas beberapa ukuran utama atau ukuran generik keberhasilan perusahaan dari strategi yang dirumuskan dan dilaksanakan dengan baik.Ukuran utama tersebut terdiri atas kepuasan pelanggan, retensi pelanggan, akuisisi pelanggan baru, profitabilitas pelanggan dan pangsa pasar di segmen sasaran.Semua ukuran tersebut dapat dikelompokkan dalam suatu rantai hubungan sebab - akibat (gambar 3). Selain itu perspektif pelanggan juga mencakup berbagai ukuran tertentu yang menjelaskan tentang preposisi nilai yang akan diberikan perusahaan kepada pelanggan segmen pasar sasaran. Faktor pendorong keberhasilan pelanggan inti di segmen pasar tertentu merupakan faktor yang penting, yang dapat mempengaruhi keputusan pelanggan untuk berpindah atau tetap loyal kepada pemasoknya. Perspektif pelanggan memungkinkan para manajer unit bisnis mengartikulasikan strategi yang berorientasi kepada pelanggan dan pasar yang akan memberikan keuntungan finansial masa depan yang lebih besar.

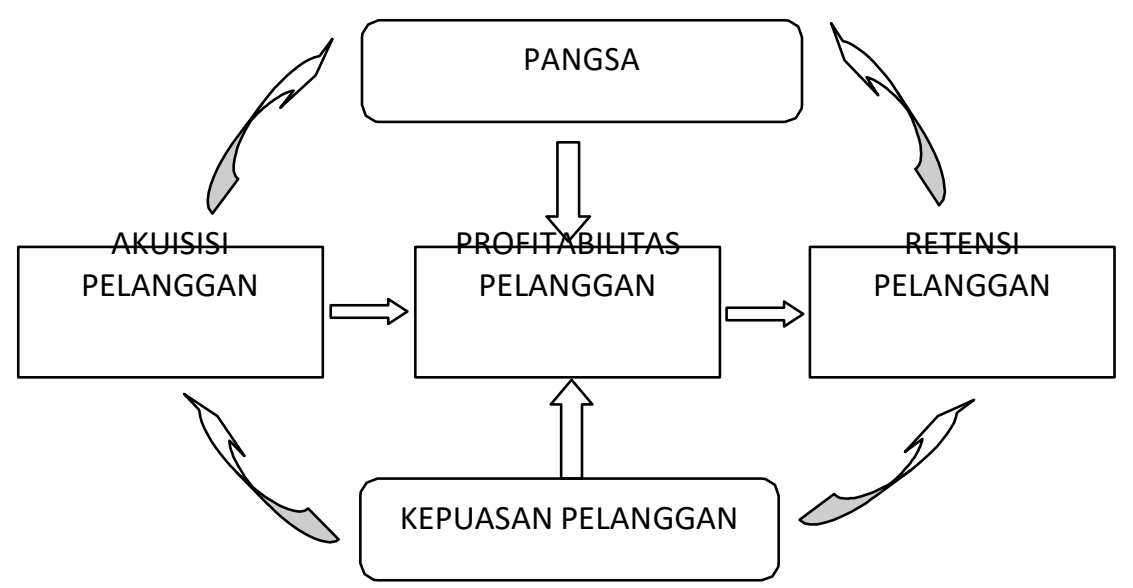

Gambar 3. Perspektif Pelanggan

Sumber: Kaplan \& Norton (2000 : 60)

\section{Perspektif Proses Bisnis Internal}

Dalam perspektif proses bisnis internal, para eksekutif mengidentifikasi berbagai proses internal penting yang harus dikuasai dengan baik oleh perusahaan. Proses ini memungkinkan unit bisnis untuk; memberikan proposisi nilai yang akan menarik perhatian dan mempertahankan pelanggan dalam segmen pasar sasaran, dan memenuhi harapan keuntungan finansial yang tinggi para pemegang saham. Ukuran proses bisnis internal berfokus kepada berbagai proses internal yang akan berdampak besar kepada kepuasan pelanggan dan pencapaian tujuan finansial perusahaan. 


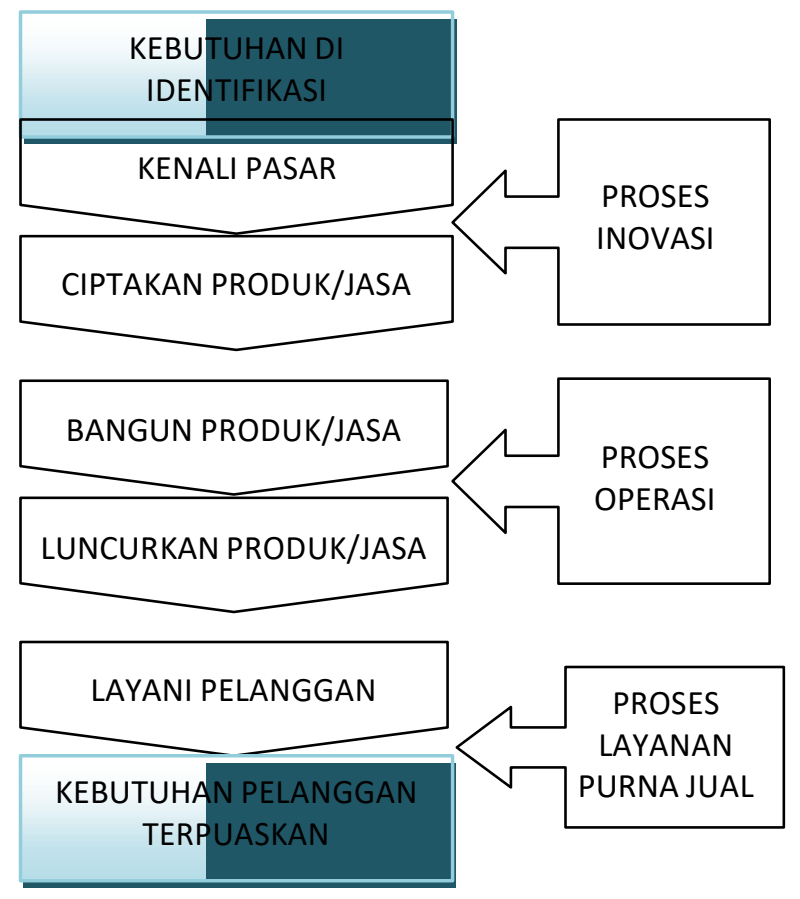

Gambar 4. Perspektif Proses Bisnis Internal-Model RantaiNilai Generik Sumber: Kaplan \& Norton (2000:84)

Dalam proses inovasi, unit bisnis meneliti kebutuhan pelanggan yang sedang berkembang atau yang masih tersembunyi, dan kemudian menciptakan produk atau jasa yang akan memenuhi kebutuhan tersebut. Proses operasi, langkah utama kedua dalam rantai nilai internal generik, adalah tempat di mana produk dan jasa diproduksi dan disampaikan kepada pelanggan. Proses ini secara historis telah menjadi fokus sebagian besar sistem pengukuran kinerja perusahaan. Langkah utama ketiga dalam rantai nilai internal adalah layanan kepada pelanggan setelah penjualan atau penyampaian produk dan jasa.

\section{Perspektif Pembelajaran dan Pertumbuhan}

Perspektif ke empat dari Balanced Scorecard yaitu pembelajaran dan pertumbuhan, mengidentifikasi infrasrutur yang harus dibangun perusahaan dalam menciptakan pertumbuhan dan peningkatan kinerja jangka panjang. Tiga sumber utama pembelajaran dan pertumbuhan perusahaan berasal dari manusia, sistem dan 
prosedur perusahaan. Tujuan finansial, pelanggan dan proses bisnis internal di Balanced Scorecard biasanya akan memperlihatkan adanya kesenjangan antara kapabilitas sumber daya manusia, sistem dan prosedur saat ini dengan apa yang dibutuhkan untuk menghasilkan kinerja yang penuh dengan terobosan. Untuk menutup kesenjangan ini, perusahaan harus melakukan investasi dengan melatih ulang para pekerja, meningkatkan teknologi dan sistem informasi serta menyelaraskan berbagai prosedur dan kegiatan sehari-hari perusahaan.

Dalam balanced scorecard ada tiga kategori utama untuk perspektif pembelajaran dan partum-buhan:

$3 / 4 \quad$ Kapabilitas pekerja

$3 / 4 \quad$ Kapabilitas sistem informasi

$3 / 4$ Motivasi, pemberdayaan dan keselarasan.

\section{Ukuran Inti}

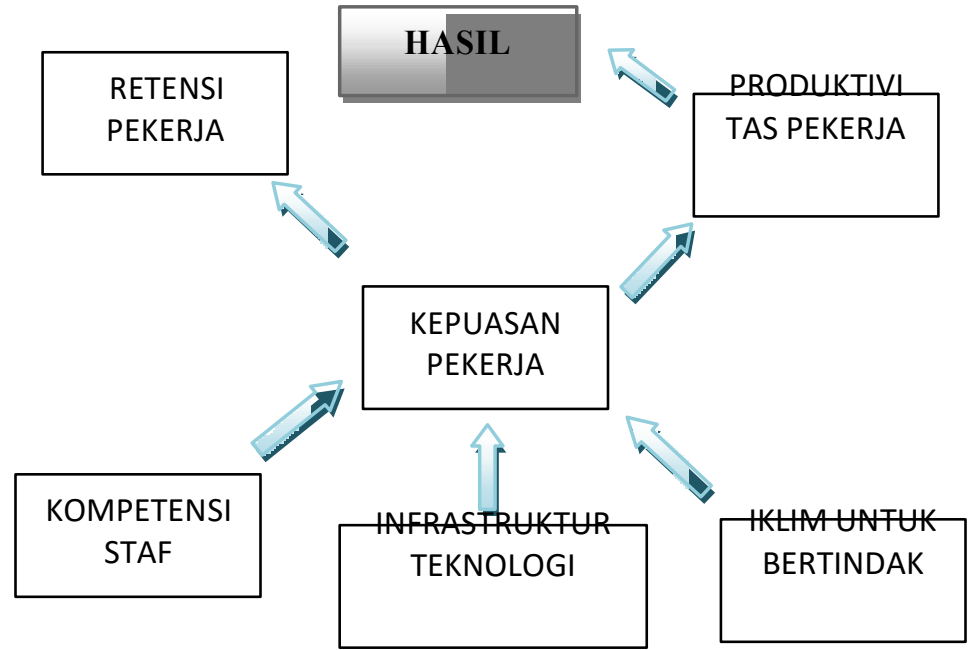

Gambar 5. Kerangka Kerja Ukuran Pembelajaran dan Pertumbuhan

Sumber: Kaplan \& Norton (2000 : 112)

\section{PENUTUP}

Keberhasilan perusahaan abad informasi akan ditentukan oleh bagaimana investasi dan pengelolaan aktiva intelektual dilaksanakan. Spesialisasi fungsional harus diintegrasikan ke dalam proses bisnis berorientasi pelanggan. Produksi massal dan penyediaan jasa produk dan jasa standar harus digantikan oleh penciptaan produk dan jasa inovatif yang fleksibel, responsif dan bermutu tinggi yang dapat disesuaikan dengan kebutuhan setiap segmen pelanggan sasaran. Inovasi dan peningkatan produk, layanan dan proses akan dihasilkan oleh parta pekerja yang mendapatkan pelatihan ulang, teknologi informasi yang superior, dan berbagai prosedur perusahaan yang selaras. 
Keberhasilan atau kegagalan perusahaan tidak dapat dimotivasi atau di ukur dalam jangka pendek oleh model akuntansi keuangan tradisional. Model finansial tersebut, pada umumnya mengukur peristiwa masa lalu, bukan investasi yang ditanamkam dalam berbagai kapabilitas yang menghasilkan nilai masa depan.Oleh karena itu perusahaan dapat menggunakan Balanced Scorecard, suatu kerangka kerja untuk mengintegrasikan berbagai ukuran yang diturunkan dari strategi perusahaan. Selain ukuran kinerja finansial masa lalu, balanced scorecard juga memperkenalkan pendorong kinerja finansial masa depan. Pendorong kinerja, yang meliputi perspektif pelanggan, proses bisnis internal, dan pembelajaran serta pertumbuhan, diturunkan dari proses penerjemahan strategi perusahaan yang dilaksanakan secara eksplisit dan ketat ke dalam berbagai tujuan dan ukuran yang nyata.

Tujuan finansial menggambarkan tujuan jangka panjang perusahaan, yaitu pengembalian modal investasi yang tinggi dari setiap unit bisnis.Penerapan Balanced Scorecard membantu tercapainya tujuan finansial ini.Balanced Scorecard dapat membuat tujuan finansial menjadi eksplisit, dan dapat disesuaikan untuk setiap unit bisnis dalam berbagai tahap pertumbuhan dan siklus yang berbeda.Dalam perspektif finansial, scorecard memungkinkan para eksekutif setiap unit bisnis untuk menetapkan bukan hanya ukuran yang mengevaluasi keberhasilan jangka panjang perusahaan, tetapi juga berbagai variabel yang dianggap paling penting untuk menciptakan dan mendorong tercapainya tujuan jangka panjang. Semua tujuan dan ukuran dalam perspektif lain harus saling terkait dengan pencapaian berbagai tujuan di dalam perspektif finansial.

Pada saat merumuskan perspektif pelanggan, para manajer harus memiliki gagasan yang jelas tentang segmen pelanggan dan segmen bisnis sasaran dan memilih serangkaian pengukuran hasil utama, yaitu pangsa pasar, retensi, akuisisi, kepuasan dan profitabilitas, untuk segmen sasaran tersebut. Para manajer juga harus mengenali apa yang dinilai tinggi oleh para pelanggan segmen sasaran dan memilih proposisi nilai apa yang akan diberikan.

Dalam perspektif proses bisnis internal, para manajer mengidentifikasi berbagai proses penting yang harus dikuasai oleh perusahaan dengan baik agar mampu memenuhi tujuan para pemegang saham dan segmen pelanggan sasaran. Sistem pengukuran kinerja konvensional memusatkan perhatian hanya pada pemantauan dan perbaikan biaya, mutu, dan ukuran berdasarkan waktu proses bisnis perusahaan. Sedangkan pendekatan Balanced Scorecard memungkinkan tuntutan kinerja proses internal ditentukan berdasarkan harapan pihak eksternal tertentu. Balanced Scorecard mengikutsertakan proses inovasi sebagai suatu komponen vital perspektif proses bisnis internal, disamping proses operasi dan proses layanan purna jual

Perspektif yang keempat adalah pembelajaran dan pertumbuhan. Kemampuan untuk mencapai sasaran-sasaran ambisius tujuan finansial, pelanggan, dan proses 
bisnis internal bergantung kepada kapabilitas perusahaan dalam pembelajaran dan pertumbuhan. Tiga kelompok ukuran berdasarkan pekerja yang utama yaitu, kepuasan, produktivitas, dan retensi, memberi ukuran hasil dari investasi yang ditanamkan atas para pekerja, sistem dan keselarasan perusahaan.

Balanced Scorecard menutup lubang yang ada disebagian besar sistem manajemen, yaitu kurangnya proses sistematis untuk melaksanakan dan memperoleh umpan balik sebuah strategi. Proses manajemen yang dibangun di seputar scorecard memungkinkan adanya keselarasan dan pemusatan perhatian kepada pelaksanaan strategi jangka panjang. Bila digunakan secara tepat, Balanced Scorecard merupakan dasar pengelolaan perusahaan di abad informasi.

\section{DAFTAR PUSTAKA}

Daft, Richard L. (2002). Manajemen, Edisi Kelima Jilid 1 dan 2, Penerbit Erlangga, Jakarta.

David, Fred .R (2005).Strategic Management, Concepts and Case Pearson, Prentice Hall.

David, Fred. R, (2006).Strategic Management, Manajemen Strategis, Salemba Empat, Jakarta.

Grant, Robert M, (1997). Analisis Strategi Kontemporer, Konsep, Teknik, Aplikasi, Erlangga, Jakarta.

Hitt, Michael.A, Ireland \& Hoskisson, (2001) Manajemen Strategis, Daya Saing dan Globalisasi, Salemba Empat, Jakarta.

Jauch \& Glueck, W (1999). Manajemen Strategis Dan Kebijakan Perusahaan, Erlangga, Jakarta.

Kaplan R.S\& Norton D.P, (2000). Balanced Scorecard, Menerapkan Strategi Menjadi Aksi, Erlangga, Jakarta.

Kuncoro, Mudrajad, 2006). Strategi, Bagaimana Meraih Keunggulan Kompetitif, Erlangga, Jakarta.

Pearce J.A\& Robinson R.B, (2008). Strategic Management, Formulasi Implementasi dan Pengendalian, Buku 1, Salemba Empat Jakarta.

Supriyono, (1998). Manajemen Strategi Dan Kebijaksanaan Bisnis, BPFE, Yogyakarta.

Thomson, Strickland, Gamble (2007). Crafting and executing Strategy, The QuestForCompetitive Advantage, Concepts \& Cases Mc. Graw Hill, Irwin.

William, Chuck (2001). Manajemen, Penerbit Salemba Empat, Jakarta. 